\section{Comorbidity and long-term outcome in patients with congenital heart block and their siblings exposed to Ro/SSA autoantibodies in utero}

We read with great interest the article 'Comorbidity and LongTerm Outcome in Patients with Congenital Heart Block and Their Siblings Exposed to Ro/SSA Autoantibodies In Utero' by Mofors et al. ${ }^{1}$ A large and long-term follow-up population consisting of patients with congenital heart block $(\mathrm{CHB})$ as a result of in utero Ro/SSA autoantibody exposure were studied. It contributes valuable information to our knowledge; however, some aspects need to be clarified and discussed.

First, there was no information related to treatment during the in utero period. Treatment modalities such as hydroxychloroquine, intravenous immunoglobulin (IVIG) and fluorinated steroids have promising results for preventing $\mathrm{CHB}$ and myopathy in these patients. ${ }^{2-4}$ Especially, the combination of fluorinated steroids with IVIG improved the condition of patients with neonatal lupus-associated cardiomyopathy. ${ }^{2} 5$ Whether patients were screened and given treatment during the pregnancy period is not stated in the study. With regard to the long follow-up period, it must be considered that these treatment modalities were not available during this period. However, it may have been the reason for some patients having cardiomyopathy on follow-up.

Second, at the beginning of the study, patients with CHB were included, but on follow-up, 97\% of the patients had an International Classification of Diseases (ICD) code consistent with $\mathrm{CHB}$ diagnosis. The difference can be explained by ICD9-10 conversion. We would like to know if there is any headling patient, so such a difference has emerged.

We appreciate the work of Mofors et al to highlight the prognosis of this rare condition. We believe that this comprehensive study will help us understand better the potential risk of $\mathrm{CHB}$ and manage these patient groups.

Hasan Satış, ${ }^{1}$ Reyhan Bilici Salman, ${ }^{1}$ Aslihan Avanoğlu Güler, Hazan Karadeniz, ${ }^{1}$ Şeyma Yıldız, ${ }^{2}$ Neslihan Kayahan ${ }^{3}$
${ }^{1}$ Rheumatology Deparment, Gazi University, Ankara, Turkey

${ }^{2}$ Internal Medicine Deparment, Gazi University, Ankara, Turkey

${ }^{3}$ Department of Internal Medicine, Gülhane Egitim ve Arastirma Hastanesi, Ankara, Turkey

Correspondence to Dr Hasan Satıs, Gazi University, Ankara 06500, Turkey; hasansats@gmail.com

Handling editor Josef S Smolen

Contributors All contributed equally.

Funding The authors have not declared a specific grant for this research from any funding agency in the public, commercial or not-for-profit sectors.

Competing interests None declared.

Patient consent for publication Not required.

Provenance and peer review Not commissioned; internally peer reviewed.

(C) Author(s) (or their employer(s)) 2019. No commercial re-use. See rights and permissions. Published by BMJ.

\section{Check for updates}

To cite Satış H, Bilici Salman R, Avanoğlu Güler A, et al. Ann Rheum Dis Epub ahead of print: [please include Day Month Year]. doi:10.1136/annrheumdis-2019-215542

Received 12 April 2019

Revised 4 May 2019

Accepted 6 May 2019

Ann Rheum Dis 2019;0:1. doi:10.1136/annrheumdis-2019-215542

\section{REFERENCES}

1 Mofors J, Eliasson H, Ambrosi A, et al. Comorbidity and long-term outcome in patients with congenital heart block and their siblings exposed to Ro/SSA autoantibodies in utero. Ann Rheum Dis 2019;78:696-703.

2 Saxena A, Izmirly PM, Mendez B, et al. Prevention and treatment in utero of autoimmune-associated congenital heart block. Cardiol Rev 2014;22:263-7.

3 Rein AJJT, Mevorach D, Perles Z, et al. Early diagnosis and treatment of atrioventricular block in the fetus exposed to maternal anti-SSA/Ro-SSB/La antibodies: a prospective, observational, fetal kinetocardiogram-based study. Circulation 2009;119:1867-72.

4 Izmirly PM, Saxena A, Sahl SK, et al. Assessment of fluorinated steroids to avert progression and mortality in anti-SSA/Ro-associated cardiac injury limited to the fetal conduction system. Ann Rheum Dis 2016;75:1161-5.

5 Trucco SM, Jaeggi E, Cuneo B, et al. Use of intravenous gamma globulin and corticosteroids in the treatment of maternal autoantibody-mediated cardiomyopathy. J Am Coll Cardiol 2011;57:715-23. 